Check for updates

The BMJ

hmacdonald@bmi.com Follow Helen on Twitter@drhelmac

Cite this as: $B M / 2022 ; 376: 0545$ http://dx.doi.org/10.1136/bmj.0545 Published: 03 March 2022

\section{Take courage, speak up, and act}

\section{Helen Macdonald research integrity editor}

The health, wellbeing, and safety of the people of Ukraine have dominated the thoughts of many people this week, after Russia's invasion of the country. Ethicist Julian Sheather reminds us how the impact of war ripples outwards, in space and time, through lives and generations (doi:10.1136/bmj.0499). ${ }^{1}$ Reports of physical trauma, and disruption to water, sanitation, and food, are just the beginning of the harms to health. What can healthcare professionals do beyond managing the physical and mental aftermath of conflict? Gareth Iacobucci reports on an open, and moving, letter to Vladimir Putin signed by thousands of Russian doctors and healthcare workers urging him to cease hostilities against Ukraine (doi:10.1136/bmj.0531; doi:10.1136/bmj.0535). ${ }^{23}$

Closer to home, political leaders have set out their action plan for dealing with the ongoing threat of covid-19. As Matthew Limb reports, more detail is needed on how testing and staffing of health services might scale up and down and how to minimise inequalities (doi:10.1136/bmj.0515). ${ }^{4}$ Many of these themes are familiar, but others, such as the importance of the Office for National Statistics' covid infection survey and the Vaccine Manufacturing Innovation Centre (VMIC), may be less so. Jennifer Beam Dowd expands on the importance of the ONS survey (doi:10.1136/bmj.0496), ${ }^{5}$ not just as a prevalence statistic but as a denominator that has allowed the UK to estimate infection fatality rates by age and helped us to understand how the population responded to vaccines as antibodies rose-and later waned. And Rebecca Glover and colleagues further challenge the government's plan to sell the VMIC to industry, outlining why this "jewel in the crown of the UK's covid-19 vaccine response" is worth saving (doi:10.1136/bmj-2022-069999). ${ }^{6}$

In the latest instalment of The BMJ's quality improvement series, Peter Davey and colleagues share advice on how to imbed QI in clinical training, a current requirement for foundation year 2 doctors (doi:10.1136/bmj-2020-055084). ${ }^{7}$ Key skills include learning to identify problems, analyse why they happen, and test change. In the past, foundation doctors might have used a problem they themselves encountered to identify a project, but results tend to be better when the problem is recognised by a broader clinical team.

Although QI can stem from clinical challenges, projects can also be in response to new evidence and guidance. Linan Zeng and colleagues look at the implications of a trial for patients with antineutrophil cytoplasmic antibody (ANCA) associated vasculitis (doi:10.1136/bmj-2021-064597). ${ }^{8}$ Their rapid recommendation article provides guidance on the role of plasma exchange and dosing of glucocorticoids in the first six months of treatment.
Guidance is given elsewhere, where Mohammad Razai and colleagues discuss the recommendations of a report by the NHS Race and Health Observatory, such as better ethnic data monitoring to improve clinical outcomes (doi:10.1136/bmj.0424). ${ }^{9}$ Quoting CS Lewis, they write that the greatest evil is "conceived and ordered (moved, seconded, carried, and minuted) in clear, carpeted, warmed, and well-lighted offices.” Their message is simple: the recommendations must be acted on.

Sheather J. As Russian troops cross into Ukraine, we need to remind ourselves of the impact of war on health. BMJ2022;376:0499. doi: 10.1136/bmi.0499 pmid: 35217578

2 lacobucci G. Ukraine invasion: Russian doctors urge Putin to cease hostilities. BMJ 2022;376:0531doi: 10.1136/bmi.0531.

3 Russian doctors, nurses, and paramedics demand an end to hostilities in Ukraine. BMJ 2022;376:0535.

$4 \quad$ Limb M. Covid-19: Is the government dismantling pandemic systems too hastily?BMJ2022;376:0515doi: 10.1136/bmj.0515.

5 Dowd JB. The UK's covid-19 data collection has been "world beating"-let's not throw it away. BMJ 2022;376:0496. doi: 10.1136/bmj.0496 pmid: 35217522

6 Glover RE, Roberts AP, Singer AC, Kirchhelle C. Sale of UK's Vaccine Manufacturing and Innovation Centre. BMJ2022;376:e069999. doi: 10.1136/bmj-2022-069999 pmid: 35197301

7 Davey $\mathrm{P}$, Thakore S, Tully V. How to embed quality improvement into medical training. BMJ 2022;376:e055084. doi: 10.1136/bmj-2020-055084 pmid: 35210255

8 Zeng L, Walsh M, Guyatt GH, etal. Plasma exchange and glucocorticoid dosing for patients with ANCA-associated vasculitis: a clinical practice guideline. BMJ 2022;376:e064597. doi: 10.1136/bmj-2021-064597 pmid: 35217581

9 Razai MS, McKechnie D, Rao M, Majeed A. Now is the time for radical action on racial health inequalities. BM/2022;376:0424 doi: 10.1136/bmj.0424 pmid: 35177403 